\title{
Geographical Indications of traditional handicrafts: a cultural element in a predominantly economic activity
}

\section{Patricia Covarrubia*}

Abstract The effect of globalization has seen a cross-cultural exchange on cultural forms and cultural diversity. This demands to seek the most effective, comprehensive, and appropriate mechanisms to safeguard and protect traditional knowledge. Established international treaties and regional/national conventions appear to cover the international trade of products but to what degree they discriminate among products is to be tested. In order to do so international and regional legislations as well as bilateral agreements between the European Union and Latin American countries will be considered.

Additionally, when handicraft is at issue the debate over the relationship between cultural heritage and intellectual property is relevant. This paper argues the topic of Geographical Indications as a tool to protect but also to safeguard and preserve traditional handicraft. By examining local frameworks and the importance of international harmony, the study will show that the protection of geographical indications goes beyond economic goals.

Keywords Geographical Indications, Traditional Cultural Expressions, non-agricultural products, Latin America, European Union, TRIPS, UNESCO

\section{Introduction}

The legislative and enforcement changes that have followed the implementation of the Agreement on Trade Related Aspects of Intellectual Property (TRIPS) and bilateral treaties have, to some degree, affected some of the Latin American countries in regard to Geographical Indications (GIs). Many countries in the region have recently started to protect and promote agricultural and non-agricultural products either through a sui generis right or as an intellectual property right (IPR). They are using these regimes as tools which are important to the nation, both economically and symbolically. These states, considered 'developing', while already having in place regulations, appear to have a lack of awareness on the local innovation capabilities that they have and of the potential economic and cultural development and attention that they could obtain. Certainly, GIs appear to be of great relevance to marketing strategies for the community involved and for the country.

However, while looking at the power that GIs may have one must not hide the other side of the coin. GIs are not for everyone and in the case of traditional handicraft, attention to traditional knowledge (TK) and traditional cultural expressions (TCEs) which touch upon the intrinsic value of cultural heritage needs attention: is TK a tradeable good? ${ }^{1}$

\footnotetext{
* Patricia Covarrubia, qualified lawyer (Venezuela) LLM (Southampton, UK) PhD (Brunel, UK) is an IP expert working at the Latin America IPR SME Helpdesk co-funded by the European Commission. She is a senior lecturer in law at the University of Buckingham, UK.

This study was presented and discussed at the 2017 Annual Conference of the European Policy for Intellectual Property, 4-6 September 2017. Thanks to colleagues for constructive feedback. The usual disclaimer applies, though.

Email: patricia.covarrubia@buckingham.ac.uk

${ }^{1}$ TK generally includes the intellectual and intangible cultural heritage, practices and knowledge systems of indigenous and local communities - called 'TK lato sensu' since it embraces the content of the knowledge itself as well as its expression (TCEs are included).

'TK stricto sensu' refers to knowledge as such including the know-how, practices, skills and innovations. Throughout this paper, the term TK will be used to refer to TK stricto sensu and not directly to TCEs, unless indicated otherwise.
} 
In the Latin America region handicraft is a traditional main sector of craft. For instance, over one million people who live directly or indirectly from the arts and crafts sector represent the artisanal sector in Colombia. ${ }^{2}$ Generally, many artisans are said to be from rural and indigenous areas and thus, there is the need to consider GIs for sustainable development, food security and cultural diversity. It is recently that states have started to focus on the development of policies to incentive local communities to protect their local products. Governmental and non-governmental organisations are paying more attention to their role in the area of GIs. While GIs may be seen as an economic tool (either as to exploit the product or as a tourism attraction) the locals could use them as a way to organise their communities and to 'safeguard' (rather than merely protect from misappropriation or passing off) their heritage (in accordance with the UNESCO 2003 Convention on Safeguarding Intangible Cultural Heritage).

Cultural decline is seen in communities, and new generations are becoming less observant of their culture. ${ }^{3}$ By asserting the use of the GI legal framework as an economic tool, acknowledgement of this as to promote and preserve culture would be enlightened. The revitalization and rescue of traditional handicraft reinforces the cultural heritage of a nation; it reflects the identity of its people. ${ }^{4}$ It is generally thought that cultural heritage deserves international protection due to its exceptional universal value, but is GI the right tool to do so? ${ }^{5}$ While a swift answer will be negative, one cannot avoid the fact that GIs can be seen as one of the instruments that may incentivise a community to work together for the same goal. Moreover, it can be linked to human development - related to improving the quality of life of local communities, promoting inclusion and strengthening their cultural identities. However, while the GI legal framework may not be the best or ideal tool for some of the traditional handicraft since there are problems in applying IP to intangible cultural heritage e.g. questions about collective rights; ownership; enforcement; preservation; to name a few, ${ }^{6}$ some communities as well as governments aim to find new markets and be able to compete in them. This is then linked to the sustainable use of cultural heritage and consequently the need to protect traditional handicraft.

The study avoids ideas of rescue, victims, stereotypes and static culture but looks forward to expose ideas and thoughts and to this end, studies GIs as a tool that can be used to protect, safeguard and preserve artisanal and indigenous handicraft. Common questions brought into debate which appear to be still relevant are: What needs to be protected? Protection against what? And is IP protection safeguarding handicraft? The paper will examine the growing relevance of IPRs to areas of cultural heritage.

This paper is divided in five parts: firstly, it attempts to define traditional handicraft and give a general overview of this product by acknowledging the idea behind culture and TK. The second part is dedicated to the framework of GIs and considers the situation of Latin American countries that have signed a bilateral trade agreement with the EU. Thirdly, an examination of the term GI towards handicraft is studied examining the national legislation for the selected Latin American countries. In this regard, examples of GI for handicraft are noted and a systematic examination of the term terroir is discussed. Part four of the paper examines how the GI regime may improve the livelihood of a community not only by protecting but also by promoting and safeguarding their culture. This last part mentions some of the projects that are run in Latin America that are helping rural communities to become more knowledgeable about IP tools.

\footnotetext{
${ }^{2}$ Castonguay (2006).

${ }^{3}$ De la Cruz (2016), p. 8.

${ }^{4}$ Ariza and Parra (2010), p. 10.

${ }^{5}$ Lenzerine (2011), p. 108.

${ }^{6}$ For background see Chan's (2014) study on ceramics craftspeople in chulucanas, Peru.
} 


\section{1. - Traditional Handicraft}

Handicraft appeals to the aesthetics of observers but also may serve a purpose. This is seen more in 'traditional handicraft' which has evolved out of basic human necessity (a utilitarian root). ${ }^{7}$ Furthermore traditional handicraft carries a cultural heritage motif and thus, comprehension on the use of such products is needed. This is so because traditional handicraft touches upon TK which do have an intrinsic value of cultural heritage, therefore: can traditional handicraft be a tradeable product?

At the international level, there is no accepted definition of TK. Some international treaties accept it as 'knowledge, innovations and practices of indigenous and local communities embodying traditional lifestyles relevant for the conservation and sustainable use of biological diversity'. ${ }^{8}$ According to the Intergovernmental Committee Report on Intellectual Property and Genetic Resources, Traditional Knowledge and Folklore (GRTKF), traditional handicrafts come within the scope of TCEs. Consequently throughout this paper the term TCEs will be used. ${ }^{9}$ WIPO's Intergovernmental Committee on Intellectual Property and GRTKF, indicates characteristics common to a TCEs such as: products of creative intellectual; transmitted from generation to generation; expressed and maintained, in a collective context, by indigenous peoples and local communities; and the unique product of and/or directly linked with and the cultural and/or social identity and cultural heritage of indigenous peoples and local communities. ${ }^{10}$

To engrave proprietary jurisprudence onto TCEs does not appear to be correct, however some traditional handicrafts are the means of livelihood for some communities. ${ }^{11}$ Their creation apart from being a cultural motion are an essential part of their economic activity. ${ }^{12}$ Therefore, a tradeable product designed to be commercialized. ${ }^{13}$ That said, the products covered in this paper covers merely products which the community or group have decided themselves to be subject to trade outside their community. ${ }^{14}$ Accordingly GIs in this regards will be seen as a matter of public interest for protection of property which evolved out of a community's collective right. ${ }^{15}$

Protecting and promoting the rights of these communities one needs to establish first what traditional handicraft is and secondly, why the need for protection and preservation: are these terms interchangeable?

Although there is no definition that will distinguish between industrial handicraft and traditional handicraft one can bring out the essential characteristic which are involved in traditional handicraft which are not present in industrial handicraft. For a start the UNESCO/ITC International Symposium on 'craft and the international market' identifies in artisanal products (differencing this with industrial ones) the 'direct manual contribution of the artisan' which 'remains the most substantial component of the finished product; ${ }^{16}$ the representation of the product is symbolic of the culture of the artisans; and finally such

\footnotetext{
${ }^{7}$ Deepak (2008), p. 197.

${ }^{8}$ Article $8(\mathrm{j})$ of the Convention on Biological Diversity (CBD). Other instruments that refer to TK are the Nagoya Protocol (to the CBD); International Treaty on Plant Genetic Resources for Food and Agriculture; and; the United Nations Declaration on the Rights of Indigenous Peoples.

${ }^{9}$ The paper does not seek to establish or debate the concept of TCE. However, it is important to establish what the meaning of this is by looking at the characteristic debated at WIPO.

${ }^{10}$ Proposed Article 2 of the Protection of Traditional Cultural Expressions: Draft Articles Facilitators' Rev. 2 (as at the close of IGC 33 on March 3, 2017).

11 Deepak (2008), p. 198.

12 Deepak (2008), p. 198.

13 Gervais (2009), p. 555.

${ }^{14}$ This leaves aside discussion of stewardship, secret and sacred TCEs, and ownership among others.

${ }^{15}$ Deepak (2008), p. 199.

16 UNESCO.ITC (1997).
} 
relationship between culture and handicraft reflect the value system of the communities reinforcing their heritage. ${ }^{17}$ These key features are also present when reading the TCEs definition proposed by WIPO ${ }^{18}$ Current GIs system do not differentiate between industrial and traditional handicraft (not that there is a requirement to do so); the rationale for making such difference is to examine that added to protection, when traditional handicraft is at issue i.e. TCEs, one needs to oversee the potential of extending protection to preserve and safeguard such products. The collateral effect of this would be to link the aims of other legal frameworks such as the United Nations Declarations of Rights of Indigenous Peoples (UNDRIP) and the UNESCO 2003 Convention on Safeguarding Intangible Cultural Heritage.

\section{1. - Protection or overprotection}

When protection is referred to, especially in the IP system, it is separated from the concepts of 'preservation' and 'safeguarding'. The latter refers to the identification, documentation, transmission and the revival of cultural heritage in order to ensure its maintenance and viability. ${ }^{19}$ A number of international declarations and agreements outside of WIPO deal with this, mainly driven by UNESCO. ${ }^{20}$

The IP system in general (be it through copyright, design rights, patents or the trade mark system) can provide to local communities and indigenous peoples both: defensive and positive protection. Defensive by protecting against offensive and deceptive uses of signs, symbols, and genetic resources and thus, preventing others from using these. The positive protection is found by allowing registration of distinctive signs or symbols, preventing commercial use of signs, symbols, and genetic resources by third parties, among other things.

When examining traditional handicraft, one can reflect on the growing importance of culture-related concerns as part of the values to be shared by the international community. As noted UNESCO is leading the way on this matter and by early 2000 it adopted the Convention for the Safeguarding of the Intangible Cultural Heritage (2003) defining what 'intangible cultural heritage' is and fitting within this definition handicraft. ${ }^{21}$ By 2005 UNESCO adopted the Convention on the Protection and Promotion of the Diversity of Cultural Expressions and while it appears that there is no link between UNESCO and IP since none of these UNESCO's Conventions refer to intellectual property, it does not necessarily mean that they do not (and cannot) work hand in hand. The GI regime embodies tradition of a region and usually embodies a cultural component which it aims to protect; UNESCO aims to safeguard and promote this. In the same vein, it is also important to mention two other international instruments; the UNDRIP and the ILO Convention 169 (Indigenous and Tribal Peoples Convention). ${ }^{22}$ The UNDRIP contains

\footnotetext{
17 Deepak (2008), p. 198.

18 Proposed article 2 of the Protection of Traditional Cultural Expressions: Draft Articles Facilitators' Rev. 2 (as at the close of IGC 33 on March 3, 2017).

${ }^{19}$ Goss (2017).

${ }^{20}$ See for example the UNESCO Recommendation for the Safeguarding of Traditional Culture and Folklore, 1989; the UNESCO Convention for the Safeguarding of the Intangible Cultural Heritage, 2003; and The UNESCO Convention for the Promotion and Protection of the Diversity of Cultural Expressions, 2005

${ }^{21}$ Intangible cultural heritage is defined as 'the practices, representations, expressions, knowledge, skillsas well as the instruments, objects, artifacts and cultural spaces associated therewith - that communities, groups and, in some cases, individuals recognize as part of their cultural heritage.'

${ }^{22}$ Latin America is the region with the highest number of ratification of the ILO Convention 169 (15 states have ratified it). The indigenous population in this region constitute a significant percentage of the total population see for example Guatemala where some $60 \%$ of its population is made up of indigenous peoples; in Mexico represents $15.1 \%$ of the total population; and in Peru it represents $14 \%$ of the national
} 
several articles that protect cultural heritage noting that all forms of cultural manifestations ${ }^{23}$ are potentially part of the IP system. ${ }^{24}$ Separately from protection, it establishes the rights of indigenous peoples to 'maintain' and 'develop' their IP over cultural heritage. Finally, the ILO Convention 169 aims to promote among other things, indigenous peoples' custom and traditions $;{ }^{25}$ significantly, it recognizes the prominence of 'handicraft', which as many other 'rural and community-based industries' is relevant 'in the maintenance of their cultures and in their economic self-reliance and development' ${ }^{26}$

Even though the aim of the IP system may not be 'preservation' and 'safeguarding' local communities and/or the indigenous peoples, the IP protection system shows that it may indirectly contribute to these. This is due to the GI regime symbolizing preservation of culture by listing and acknowledging the traditional use of a natural resource, or a traditional knowledge developed in a region and/or the use of traditional methods of production. In this sense, a GI will preserve and safeguard and also promote not only a region but its culture.

Recognising and granting GIs to traditional handicraft can fulfill protection, preservation and safeguarding. For instance, a certified GI will grant protection by excluding others from exercising any right in respect of such GIs i.e. avoiding misappropriation and granting exclusive economic rights; and preservation and safeguarding is effective by the community identifying and revitalizing it, ensuring its continued survival. As we evolve in these pages, the GI system is seen as capable of 'protecting' collective rights and 'preserving' tradition. Yet, by using this regime caution is required to ensure that such communities do not lose out on its identity.

Finally, when covering 'protection' rather than bringing the repetitive debate that there is a 'overprotection' of issues in the IP system we can move swiftly from this and bring in positive arguments like 'preservation', 'safeguarding' and 'promotion'.

\section{2. - Framework of Geographical Indication}

Geographical Indication is a distinctive sign which is used in trade to identify a product as originating in the territory of a particular country, region or locality; such link known as terroir is what makes the quality, reputation or other characteristic of the product to be distinctive from others. A GI typically includes the name of the place of origin but not necessarily a region. For example, Chulucana, is a district in Peru, and is used to identify pottery; Mopa Mopa Barniz-Pasto is the name of a magic bush located in the Amazon jungle, and the GI identifies art decorated by mopa mopa, a phenolic resin in Colombia; and Wayuu textiles in Colombia, where Wayuu identifies an ethnic group of the Guajira Peninsula. Such names may be used by all organisations/associations from the region that produce, elaborate, or extract such product and comply with other requirements established by a competent national office. ${ }^{27}$

GIs can be misused by producers with no link to the designated place of origin who try to profit from the reputation of the original products. Protecting a GI ensures fair

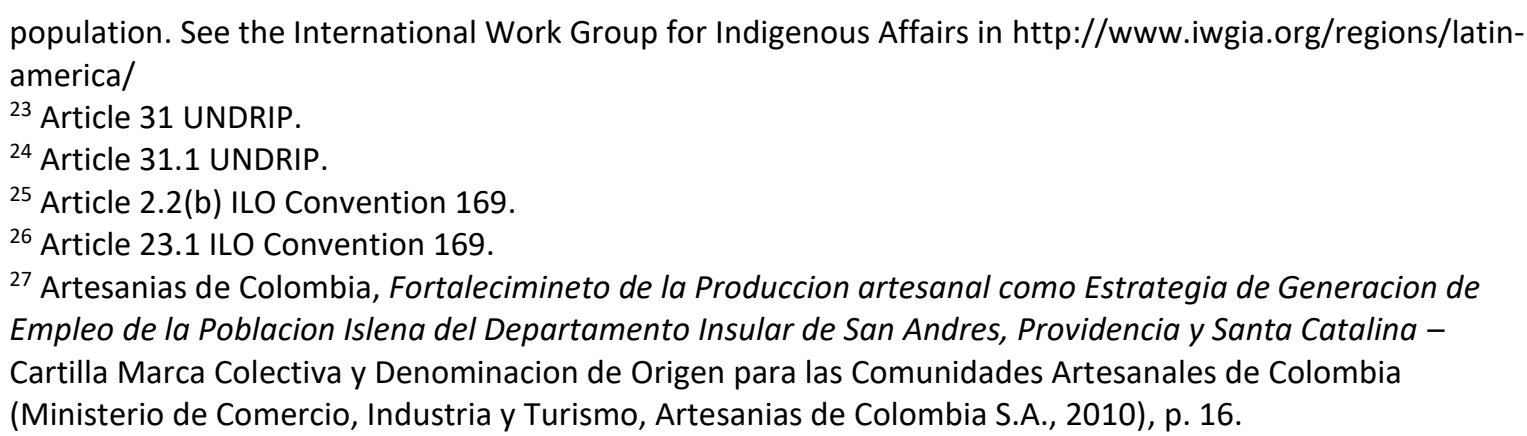


competition for producers and provides consumers with reliable information on the place of production or specific characteristics of a product.

The term 'geographical indication' was first used internationally by the TRIPS Agreement. ${ }^{28}$ Before TRIPS, international agreements such as the Lisbon Agreement for the Protection of Appellation of Origin and their International Registration; the Convention on the use of Appellation of Origin and Denominations of Chesses; and the Paris Convention, protected products which have a reputation connected with their place of origin but referring to them by using the term 'Appellation of Origin' (AO) in the first two legislation and 'Indication of Source' (IS) in the latter. While the term AO conveys all that is under the term GI, it goes farther than this. It covers a 'geographical environment' that includes 'natural and/or human factors' not seen in GIs. ${ }^{29}$ The other evident difference is that when TRIPS refers to GI it uses the word 'goods' rather than 'products' as noted by the Lisbon Agreement - the dissimilarity being that goods does not encompass 'services' while the word 'products' is not limited to wine, spirits, agricultural products and foodstuff. ${ }^{30}$

Going back to the previous point on GI definition and the different conceptualization taken by different legislatures, it is acknowledged that the definition of GIs in TRIPS differs from some countries in Latin America. The majority of countries in the region follow the Lisbon Agreement definition ${ }^{31}$ and thus, it is common to find terms such as 'Appellations of Origin' rather than GI. As noted, AOs set higher criteria for recognition than those for GIs defined in TRIPS. Seen this as a burden for some countries and due to the lack of Lisbon's membership, the Geneva Act of the Lisbon Agreement ${ }^{32}$ was adopted (May 2015) expanding the application of the system to 'geographical indications' as defined in the TRIPS Agreement; it enlarges the system to denomination of products having a weaker link with their geographical origin. ${ }^{33}$ In accordance to the region legislation, when products have a weaker link than the one required for AOs, there is still the possibility to register such products as IS or GIs.

Examining the definitions brought by these international agreements it can be said that handicraft is protected as GIs under the provision of international instruments such as the TRIPS Agreement (one of the most important multilateral agreement for the international protection of IP in general), and the Lisbon Agreement for the Protection of Appellation of Origin and its Registration. Both international frameworks are open to agricultural and non-agricultural products. This is not however the case in the EU where the GIs system only protects wines, spirits, agricultural products and foodstuff. ${ }^{34}$

A final remark is that the framework of GIs at a national level has flourished around the world. There are more than 160 national legislation providing a mechanism for registration and/or protection of GIs. They may follow two distinct approaches: on one hand based of sui generis rights and on the other, as part of an existing mark-based system. ${ }^{35}$ It seems then that protecting GIs from misleading indications and acts of unfair

\footnotetext{
${ }^{28}$ Gervais (2009), p. 560; Covarrubia (2011), pp. 330-338.

${ }^{29}$ Gervais (2009), p. 560.

${ }^{30}$ Gervais (2009), p. 560; Covarrubia (2016), pp. 129-131. Due to this wide understanding of the word 'products' Brazil extends the Gls regime to protect even services.

${ }^{31}$ This is not to be misunderstood with the fact that only 5 countries in the region are members of the Lisbon Agreement (out of the 28 members).

32 In line with the previous discussion regarding 'products' and goods', the Geneva Act opted to use the term 'good'.

33 Thi Thu Ha (2017).

${ }^{34}$ Covarrubia (2016), pp. 129-131.

35 Parasecoli (2017), p. 13.
} 
competition is a done deal. Yet the international legal position on GIs is flawed when signing bilateral trade agreements, especially if one of the parties is the EU. Bear in mind that the EU is authorized to negotiate trade agreement on the field of GIs and not the members States of the EU. ${ }^{36}$

\section{1. - Bilateral Agreements and negotiating GIs: The EU}

While the state of affairs of the EU concerning GIs is one of the most advanced ones, there is currently no EU-wide system of GI protection for non-agricultural products. ${ }^{37}$ Trade negotiations has seen Latin American countries, which already have certified handicraft under the GI system, left with no products to negotiate under the section GI, due to their counterpart not recognising such products as to be protected under the EU GIs regime. EU bilateral trade agreements contain important levels of protection for GIs. This is noticeable in the Trade Agreement between the EU and Colombia and Peru ${ }^{38}$ later on joined by Ecuador $;{ }^{39}$ and the Comprehensive Association Agreement between the EU and Central America (including Honduras, Nicaragua, Panama, Costa Rica, El Salvador, and Guatemala). ${ }^{40}$ These are the countries selected to examine this topic.

Trade is business, and Latin American countries appreciate the EU as one of their biggest partners. The EU is the third-largest bilateral trading partner in the Andean countries (Bolivia, Colombia, Ecuador and Peru) ${ }^{41}$ and one of the principal investors worth around $€ 27.7$ billion. ${ }^{42}$ The trade flow between the EU and Central America amounts to EUR 11.6 billion. ${ }^{43}$ Moreover, the deepening of trade by the Latin American region is expected to increase and expand due to the growing protectionism in the US. ${ }^{44}$ In any case, the non-agricultural sector is also part of trade negotiations; although this sector is mostly composed of micro, and small and medium enterprises (SMEs). In the case of handicraft, this sector is usually run by micro businesses that are formed of artisans and/or indigenous communities.

The Latin American population is estimated at 633 million and according to the World Bank $8 \%$ of the entire population is indigenous. ${ }^{45}$ In the framework of these negotiations such communities are not benefiting from these negotiations in regard to their

\footnotetext{
${ }^{36}$ Thi Thu Ha (2017), p. 43.

${ }^{37}$ The European Commission is exploring the possibility of extending GI protection to non-agricultural products.

${ }^{38}$ The trade agreement has been provisionally applied with Peru since 1 March 2013 and with Colombia since 1 August 2013. Official Journal of the European Union, L 254, 21 December 2012.

39 The EU with Ecuador, Colombia and Peru, signed the Protocol of Accession of Ecuador to the Trade Agreement on 11 November 2016. On 1 January 2017 Ecuador joined the Trade Agreement. Official Journal of the European Union, L 356, 24 December 2016.

${ }^{40}$ The trade has been provisionally applied at different times: Honduras, Nicaragua and Panama since August 2013, Costa Rica and El Salvador since October 2013, and Guatemala since December 2016. Official Journal of the European Union, L 111, 15 April 2014.

${ }^{41}$ Originally the Andean Community was formed by 6 states. In 1976 Chile withdrew its membership and in 2006 Venezuela left the Andean Community.

${ }^{42}$ See European Commission Country and regions: Andean Community, available at http://ec.europa.eu/trade/policy/countries-and-regions/regions/andean-community/ (accessed 30 May 2018).

${ }^{43}$ See European Commission Country and regions: Central America, available at http://ec.europa.eu/trade/policy/countries-and-regions/regions/central-america/ (accessed 30 May 2017

44 The Economist (2017).

${ }^{45}$ See World Bank Indigenous Latin America in the Twenty-First Century, available at http://www.worldbank.org/en/region/lac/brief/indigenous-latin-america-in-the-twenty-first-century-briefreport-page' (accessed 21 June 2018).
} 
GIs products considering that all signed agreements (previously mentioned) provide local protection for wine, spirits, agricultural products and foodstuff GIs but not for nonagricultural products. These agreements have closed off future market-access opportunities to these communities, thus, restricting international trade, and limiting competition. While producers can still protect their GIs according to the laws applicable in each EU member state $^{46}$ (usually by the marks regime), GIs' products would help better penetrate the EU market and increase their market share. ${ }^{47}$

For instance, in 2009 the European Directorate General for Trade commissioned a study on the protection of GIs for handicraft, which showed that most of the third country products experience growth and have export rates that tend to increase. The study also revealed that the number of jobs provided by the non-agricultural GI products are economically important for their region of origin. ${ }^{48}$ Considering this study, one questions the unbalance of non-agricultural products that were not part of the GIs table of negotiations; this is a loss for Latin America since around 25 per cent of the registered GIs in Latin America are for non-agricultural products. ${ }^{49}$ Latin American producers that have a GI for handicraft then encounter this burden. Opening this debate a clear option is given; for example, they can obtain legal protection by using the European Union Trade Mark (EUTM) regime (previously known as a Community Trade Mark (CTM)) which allows for the protection of geographical names under certain conditions. ${ }^{50}$ However, none of the Latin American GIs handicraft searched for, have been granted protection; the exception was chulucanas (a DO for pottery from Peru), ${ }^{51}$ however this was registered to a company named Chulucanas S.L. registered in Madrid Spain for goods under Nice classification 14, $21,35^{52}$ - though no link to chulucanas in Peru was noted.

In Latin America, apart from the GI regime that protects handicraft, there are other legislation aiming not only to the protection of handicraft but aimed at the preservation and safeguarding of cultural heritage. However, while there is special recognition in many national constitutions ${ }^{53}$ and regional legislation in regards to collective IPRs related to genetic resources, and TK, the view is that not many have taken specific actions that provide protection through a national standard. The exception been Panama with a sui generis regime that governs the collective rights of indigenous peoples for the protection and defence of their cultural identity and their TK - i.e. Law No. 20. The Andean countries also have a special recognition for the protection of TK known as Decision 391 on Genetic

\footnotetext{
${ }^{46}$ As indicated for example in the Trade Agreement between the EU and Colombia and Peru, article 207(d).

${ }^{47}$ See the study run by the European Commission, Results of the public consultation and public conference on the Green Paper Making the most out of Europe's traditional know-how: a possible extension of geographical indication protection of the European Union to non-agricultural products (COM(2014) 469 final (15 July 2014).

48 OriGin and Agridea (2009).

${ }^{49}$ Covarrubia (2017).

${ }^{50}$ European Commission, 'Geographical-indications' (European Commission, 28 June 2013). <ttp://ec.europa.eu/trade/policy/accessing-markets/intellectual-property/geographical-indications/> (accessed on 23 June 2018).

${ }^{51}$ Dossier No 273038-2006. Resolution 011517.

52 EUTM number 004074449. Expired in 2014.

53 See Ecuador: Constitution art 84 and Intellectual Property Law art 377; Peru: Constitution art 89. All Andean countries are signatories of the ILO Convention No. 169 on Indigenous and Tribal Peoples and, the Convention on Biological Diversity (CBD).
} 
Resources; other states have laws that establish the obligation for the state to protect cultural heritage ${ }^{54}$ but none actually have a pragmatic approach to it.

In the international arena, there is no protection of TCEs. Since 2010 WIPO's Intergovernmental Committee on Intellectual Property and GRTKF has undertaken textbased negotiations trying to reach an agreement on a text of an international legal instrument aiming to ensure the effective protection of TK, genetic resources and TCEs. ${ }^{55}$ While this continues to evolve there is nothing that deters a country to use what exists in their national legislation and take the best of it; rather than be passive and wait, there is a need for governments and NGOs and communities to be more pro-active. Indeed, the GI regime requires joint work between producers/associations and between public and private sectors. ${ }^{56}$

Setting aside the debate that TCEs deserve their own set of regulations and the fact that for some products the GI system is not adequate, the aim of this paper is to enhance what there is and remind that 'some' of the TCEs which are already in trade can benefit from the GI system to protect and safeguard traditional handicraft. Therefore, they ought to be negotiated when discussing bilateral trade agreements.

\section{3. - GI for handicraft: is the law protecting?}

According to the TRIPS Agreement and the Lisbon Agreement (and its counterpart the Geneva Act) linking products and their reputation to their places of origin applies to agricultural and non-agricultural product. ${ }^{57}$ This is not the case in the common EU regime $^{58}$ due to GIs being limited to agricultural products and foodstuffs along with wines and spirits. In other states, there is however recognition of GIs for handicrafts, especially in the regions of Asia $^{59}$ and Latin America. It is known that some EU member states identify and recognise GIs for non-agricultural products e.g. Krasliché for musical instruments located in the town of Kraslice, Czech Republic, ${ }^{60}$ Poterie de Vallauris for pottery from the municipality of Vallauris, France, ${ }^{61}$ but trade agreements are negotiated by the EU rather than by individual states.

According to international fora, the GI system protects a product, whatever the product is; there is no need to place a different method according to a product-based approach. This is observed in current debates at the WTO, which under the Doha Round put under the radar the discussion of the discriminatory GI regime as only wines and spirits enjoy higher level of protection. The other relevant debate heard at this level, is that many countries (including the EU), are keen to have a 'global registry that would protect place

\footnotetext{
${ }^{54}$ Colombia: Law No. 397 of 1997 art 4 and art 13 and Law No. 99 of 1993 art 22; Venezuela: Organization Act on Indigenous Peoples and Communities articles 101-103; Law No. 530 of May 23, 2014, on Bolivian Cultural Heritage.

${ }^{55}$ Since 2000 WIPO is trying to clarify the legal status of indigenous peoples and TK. See Parasecol (2017), p. 16.

${ }^{56}$ United Nations Economic and Social Commission for Asia and the Pacific (UNESCAP), 'Geographical Indications: Experiences in Peru' http://www.unescap.org/sites/default/files/Session18Geographical\%20Indications-Peru.pdf (accessed on 06 June 2018).

${ }^{57}$ Marie-Vivien (2016), pp. 292-326; Marie-Vivien (2017), pp. 221-252.

58 In Europe there are some national legislation that recognise GIs for handicraft; France recently adopted such position.

${ }^{59}$ Marie-Vivien (2016), pp. 292-326; Marie-Vivien (2017), pp. 221-252.

${ }^{60}$ Executive Order N ${ }^{\circ}$ MSP 22/Dr.P/66-107 of December 12, 1966 of the Ministry of Consumer Affairs.

${ }^{61}$ Law of May 6, 1919 regarding the protection of appellations of origin; Executive Order of the Cour de Cassation (Civil Chamber) of November 18, 1930.
} 
names covered by GIs as unique for the purposes of labelling ${ }^{62}$ products. If this is to happen, any WTO will have the right to registry, under this proposed international registration, handicraft. One then questions how this will be recognised in countries which do not protect non-agricultural products as GIs.

In general, while the EU currently does not have a harmonised GI regime for nonagricultural products, EU stakeholders favours an EU system of protection based on GIs for non-agricultural products. ${ }^{63}$ This goes in line with the international framework on GIs that establishes the same criteria: a 'link' between 'all kind of products' and their reputation with the place of origin and thus, no discrimination noted among types of products. Consequently, the European Parliament has called on the Commission to propose a legislative scheme establishing a harmonised GI European system for nonagricultural products. ${ }^{64}$

\subsection{National legislation for the selected Latin American countries}

In Latin America, the majority of states either have legislature regulating GIs as a separated law, or included in their national IP legislation. In addition, Cuba, Costa Rica, Nicaragua, Mexico and Peru have signed the Lisbon Agreement. Costa Rica, Nicaragua and Peru have signed the Geneva Act.

Concerning the selected countries, Colombia, Peru, and Ecuador ${ }^{65}$ use the term GI as a general category and divide this into two tiers of protection: Denomination of Origin (DO) and Indications of Source (IS). ${ }^{66}$ The latter does not have the necessary link to the 'geographical environmental' including natural and human factors required by DOs. An IS is just a name, expression, image or sign that designates or evokes a particular country, region, locality or place. ${ }^{67}$ This means that these products have a 'weaker link' so that the production of the raw materials and/or the development and/or processing of a product do not necessarily have to take place 'entirely' in the defined geographical area, just one of them needed to be. None of these Andean Communities states have registered products in their IS category - it is not clear whether there is a proper mechanism to obtain it since the legislation does not acknowledge this, as it does for DO (the administrative procedure and entitlements). ${ }^{6}$

In these jurisdictions, DOs are in line with the AO according to the Lisbon Agreement and in line with the European system of Protected Denomination of Origin (PDO) ${ }^{69}$ DOs are granted the highest level of protection, which prevents expressions such as 'kind', 'type', 'style' and 'imitation' or other similar terms that mislead the consumer even when the true origin of the product is indicated. ${ }^{70}$

\footnotetext{
62 Barham (2003), pp. 127-138.

63 European Commission Consultation ended on October 2014.

${ }^{64}$ European Parliament Resolution of 6 October 2015 on the possible extension of geographical indication protection of the European Union to non-agricultural products.

65 Brazil too.

66 The new Geneva Act introduces two tiers of protection: AO and Gls. The difference between the two is that the latter has a weak link with the place of origin. Bear in mind that the Paris Convention refers to Indication of Source.

${ }^{67}$ Art. 221 Decision 486 - Andean Community. The Paris Convention also uses this term.

${ }^{68}$ This is not the case in Brazil where several Indication of Source products have been registered.

${ }^{69}$ Observe that the Spanish version of Decision 486 (regulating Colombia, Ecuador, Bolivia and Peru) refers to 'Denominación de Origen'. The English version refers to Appellation of Origin. The DO term is the one used across this paper as to maintain it closed to what their legislators wished for.

${ }^{70}$ See Art. 23 TRIPS which is only given to wines and spirits.
} 
Bolivia's ${ }^{71}$ legislation only has one category of protection, which is for DO. In Central America Costa Rica, El Salvador, Guatemala, Honduras, Nicaragua and Panama their legislation protects GIs and has two tiers of registration: DOs and GIs (similar to the EU regime: Protected Denomination of Origins (PDOs) and Protected Geographical Indications (PGIs)).

\subsection{1. - Andean Countries}

Decision 486 is the Common Provision on Industrial Property, a common regime of the Andean countries. Under Title 'Geographical Indications' it divides GIs into Chapter I for DO and Chapter II for IS. Legislation is open to 'any' product.

Bolivia: National Applications are submitted to the Servicio Nacional de Propiedad Intelectual (SENAPI) which is the national Intellectual Property Office. Bolivia has registered a few DOs $;^{72}$ only one is for a non-agricultural product, which is Textileros de Cochabamba (for textiles) from the Cochabamba Department.

Colombia: Twenty-five DOs are registered, ${ }^{73} 11$ appear under the title 'Crafts'. They are: Cerámica de Ráquira from the municipality of Ráquira, which identifies ceramics elaborated based on the techniques inherited from the Laches people $;{ }^{74}$ Cestería en rollo de Guacamayas from the municipality Guacamayas which identifies baskets elaborated by using the techniques inherited from the pre-Columbian Lache culture ${ }^{75}$ Tejeduria Wayuú (for cotton and textile fabrics) coming from the geographical area La Guajira which is the demographic distribution of the Wayuú people ${ }^{76}$ Tejeduría Zenú (for weaving) from an indigenous reservation for the Zenú people ${ }^{77}$ Tejeduría San Jacinto (for cotton and textile fabrics) from the geographical region San Jacinto Bolívar; ${ }^{78}$ Sombrero Aguadeño (for hats) from the municipality of Aguadas, the origin dates back to the last century; ${ }^{79}$ Sombrero de Sandoná (hats) covering 13 municipalities, one of them named Sandoná, the traditional hat takes back more than 100 years and it has been transmitted from generation to generation among families $;{ }^{80}$ Cerámica del Carmen de Víboral (for ceramics) from the municipality del Carmen de Viboral; ${ }^{81}$ Mopa Mopa Barniz-Pasto (wooden art polished) from the region Pasto; ${ }^{82}$ and Sombrero Suaza (for hats) which origin dates back to 1565 from the people Andakies and today made by women weavers in the town Suaza. ${ }^{83}$ The eleventh name which appears under the same title is: Rosa de Colombia (for roses), there is no explanation why this agricultural product is under this list since other similar DOs products such as Clavel de Colombia (for carnations) and Crisantemo de Colombia (for chrysanthemum) are under the title 'Agro alimentary'. Applications are submitted to the Superintendence of Industry and Commerce (SIC) which operates the national Industrial Property Office.

\footnotetext{
${ }^{71}$ Mexico too.

72 Quinua Real del Antiplano Sur Bolivia (for quinoa), Aji Chusquisaqueño (for chilli) and Singani (for spirit).

${ }^{73}$ Superintendencia de Industria y Comercio, 'La Superintendencia en el corazon de las Denominacion de Origen' (SIC noticias) at http://www.sic.gov.co/noticias/la-sic-en-el-corazon-de-las-denominaciones-deorigen (accessed on 04 October, 2018).

${ }^{74}$ Resolution 66272, 29 November 2010.

${ }^{75}$ Resolution 30000, 19 June 2009.

${ }^{76}$ Resolution 71098, 07 December 2011.

77 Resolution 71097, 07 December 2011.

78 Resolution 70849, 06 December 2011.

${ }^{79}$ Resolution 69302, 30 November 2011.

${ }^{80}$ Resolution 69304, 30 November 2011.

81 Resolution 71791, 12 December 2011.

82 Resolution 70002, 30 November 2011.

${ }^{83}$ Resolution 29488, 01 June 2015.
} 
Ecuador: same as Colombia and using the same legislation, it recognises DOs and IS. Ecuador has registered four DOs for agricultural products (two for coffees, one for cacao and another one for peanuts), and only one for non-agricultural product, that is Sombrero de Montecristi (for hats) made in Cantón Montecristi. ${ }^{84}$ This hat has centuries of tradition, dating back to the pre-Columbian era. In this example one sees the transboundary issues that are present between IP and cultural heritage. More specifically, in 2012 UNESCO declared this straw hat as 'intangible cultural heritage'. One of the willingness of Ecuador to have the hat recognised was in the hope that the world would stop calling its famous hat the 'Panama Hat'. According to the Resolution not only does the raw material have to come from the region but the artisans 'must be native' from the region.

Applications are submitted to the Ecuadorian Institute of Intellectual Property (IEPI).

Peru: same as the other Andean countries in regard to legislation and approach. It has registered 10 DOs one of which is for handicraft. Chulucanas is registered for pottery (from the region of Chulucana) where the human factors are connected to the application of ancestral techniques (pre-Inca cultures "Vicus" and "Tallan"). Applications are submitted to the National Intellectual Property Office (INDECOPI).

\subsection{2. - Central America}

The Central America experience in regard to GIs is scarce and according to the International Centre for Trade and Sustainable Development it is even 'frustrating'. ${ }^{85}$ All national laws were drafted on the model of the Paris Convention and therefore very similar.

In all six countries examined, their current legislation concerning GIs appear to be incorporated either into the Industrial Property Law ${ }^{86}$ or into the Trade Mark Law. ${ }^{87}$ Nevertheless, in general the launch of the GI regime has seen several limitations in these countries such as: inadequate legislation; no technical administrative structure; 'low level of knowledge and experience in government institutions and in the productive sectors', and finally, GIs seem to be 'not part of the government's policies or priorities' ${ }^{88}$ It is familiar that the GI regime is 'demanding and requires an important organizational capacity and technique to meet the requirements of registration.' For instance, by 2007 in Costa Rica there were 45 nationals GIs in the process of registering and only a few have managed to do so. ${ }^{89}$

None of the Central America countries studied have yet registered a GI for nonagricultural product. ${ }^{90}$ Yet, potential is seen for Cerámica Negra de Jinotega (Nicaragua),

\footnotetext{
${ }^{84}$ Resolution No. 988698, 20 March 2007.

85 Paz and Pomareda (2009), pp. 1-23.

${ }^{86}$ Guatemala's Decree 57-2000, Industrial Property Law regulates GIs. Honduras: the GI regime is regulated by the Industrial Property Law (Decree N 12-99-E). Panama, Industrial Property Law 35, 1996 regulates Gls.

${ }^{87}$ Costa Rica regulates GIs under Law 7978, 2000 Trade Marks and other Distinctive Signs. Nicaragua: regulated by the Trade Marks and other Distinctive Signs Law (Law N 380, 2001). El Salvador regulates GI under Law 868, 2002 Trade Marks and other Distinctive Signs.

88 Paz and Pomareda (2009), pp. 1-23.

89 Paz and Pomareda (2009), pp. 1-23.

${ }^{90}$ Costa Rica has registered Café de Costa Rica (GI), Banano de Costa Rica (GI) and Queso Turrialba (for cheese) (DO) - there is a pending DO for Tarrazú (coffee). Guatemala's has registrations for Acatenango (for coffee), Café Antigua, Ron de Guatemala (GI). Honduras registered DOs have been only on the coffee sector as follows: Café de Marcala (DO) - Resolution No 012011 conacafe which was the first national DO registered in the whole Central America, Honduras Western Coffee's (GI), Cafés del Occidente Hondureño, Café Camapara , Café Cagual, Café Congolon, Café Erapuca, and Café Guisayote. Nicaragua has two DOs: Café de Nicaragua, and Queso Chontales. Finally, El Salvador has three DOs: Apaneca-Ilamatepec (coffee) Bálsamo de El Salvador (Decree No 162) and Café de Marcala.
} 
Maya textiles (Guatemala), ${ }^{91}$ San Sebastián textiles and Ilobasco handicraft (both from El Salvador) and Kuna textiles (Panama). ${ }^{92}$

Bear in mind that in Panama there is a sui generis law (approved in 2000) known as Law No. 20 'on Special System for the Collective Intellectual Property Rights of Indigenous Peoples for the Protection and Defense of their Cultural Identity and their Traditional Knowledge'. The law was made in cooperation with the Panama Ministry of Trade and Industry, and with the assistance of WIPO ${ }^{93}$ The law creates a system of registration ${ }^{94}$ and among the registered ones, a few are handicraft such as: Mola (Morra) Kuna Panama ${ }^{95}$ (textiles), Nahua or Naun (dress), Chácara o Kra (natural fiber bags), tagua (nut carvings), hand-beaded Chaquira (necklaces), ${ }^{96}$ Ologuadule (Kuna hammock) ${ }^{97}$ and finally 15 instruments using the label Gammugandi. ${ }^{98}$

\section{2 - Handicraft and the regulation of terroir}

The identification of GI products is justified by the particular local context in which they originate. It gives them a specific nature, quality or reputation in the consumers' eyes. ${ }^{99}$ The basic definition of GIs includes a 'place' name that identifies the products that originate in it and have some peculiarities that are associated with the place. Non-geographical names are also protected if they are 'linked' to a particular place. ${ }^{100}$ Examples of DOs given in this paper are terroir based product. For instance, the raw materials used in the handicraft such as straw, clay, wood and the like come from an allocated geographical region. However, this may not always be the case. For illustration, if a product does not have a DO status but may claim a GI or a IS, there is no need for the raw material to come necessarily from such place. What is needed is for some of the stages of production to reside within such region and thus, still within the meaning of terroir as they are part of a place/region.

To extend this issue of terroir and using examples of GIs previously noted, one may question: when the name given to a DO is a non-geographical name but the name of a community e.g. Wayuú, and that community is displaced, will they lose the DO?

Displacement is common to indigenous people, so the assumption is created. Will then the DO still be valid? For example, if the Zenú people are displaced from their region, can they still use the DO Tejeduría Zenú?

Bear in mind that the GI regime allows amendments to their own regulation and set of rules. For instance, if the criteria just notes a particular region this can be amended and or extended. However, the matter of terroir is what brings the GI regime to be trigged. If there is no 'link' to the place, can a community claim GI protection? It can be argued that

\footnotetext{
91 The National Mayan Weavers Movement has proposed a legal strategy (Law No 5247) which has been formally accepted and must go now through Congress to protect its legacy and ensure that the intellectual property of indigenous peoples is recognized. While the idea is first to protect the güipiles (distinctive clothing of the Mayas), the reform is expected to benefit more art crafts. See Fernandez (2017).

92 Lucas (2014).

93 OMPI (2012).

${ }^{94}$ The registration is under the jurisdiction of the Department of Collectives and Folkloric Expressions of the General Directorate of Industrial Property (DIGERPI) of the Ministry of Commerce and Industries.

95 Resolution No. 1, 22 November 2002 DIGERPI.

96 WIPO (2015).

97 Resolution No. 13297, 22 July 2009 DIGERPI.

98 Resolution No. 13298, 22 July 2009 DIGERPI.

${ }^{99}$ Food and Agriculture Organization of the United Nations (FAO) and SINER-GIFAO (2010), p. 3.

${ }^{100}$ See European Commission Geographical-indications at http://ec.europa.eu/trade/policy/accessingmarkets/intellectual-property/geographical-indications/ (accessed on 07 June 2018).
} 
GI not only relates to a place or territory, but represents a collective property. ${ }^{101}$ If we are covering 'traditional' handicraft they not only refer to a place but also to 'cultural heritage', which contains a history of production. ${ }^{102}$ A geographical name label or the like, carries messages to the consumer about quality or ingredients and also informs about the process of production. ${ }^{103}$ So rather than informing the consumer where the product was made (an origin function), it informs by whom the product was produced. ${ }^{104}$ Perhaps a different type of GI is needed for these products such as the Traditional Speciality Guaranteed (TSG) used in the European regime that aims to highlight a traditional production process rather than a region as such. ${ }^{105}$

A GI links production to the social, cultural and environmental aspects of 'particular places'. And while the terroir concept has been fully explained by many, the definition has always been connected to agro-food, always establishing a connection with place 'and' tradition. ${ }^{106}$ As a result, if a unique place produces unique products then it cannot be replicated somewhere else. ${ }^{107}$ Accordingly, if the product is to be produced in another place, due to the different environmental influences, it is bound to get a variation of the product. According to Prof Gangjee, geographical factors leave its traces upon the end product. ${ }^{108}$ There is a strong interaction between natural and social factors, which is reflected in the concept of terroir. ${ }^{109}$ Consequently the product result is a characteristic brought by and linked to their local natural and human environment. ${ }^{110}$ Literature insists upon a strong link in the production to the 'ecology and culture of specific places' which 're-embed a product in the natural processes and social context of its territory.' 111 This means that when the place does not exist anymore the geographical name protected by registration will cease to exist. However, the production process tells the story on 'how social systems of coordination and organization legitimate and perform a given interpretation of the product'. ${ }^{112}$

That said GIs do not belong to producers as such. Producers can use the GIs for their business if they fit the criteria -- the term is attributed to the place and its inhabitants. ${ }^{113}$ However, when the term is not a region but a community e.g. the Wayuu and Zenú people, can the GI travel with them? Distinctive features of a product while coming from a community they have emerged due to socio-economic or cultural factors which are specific to the region of origin and so connected with the environment. ${ }^{114}$ This interpretation goes in line with terroir as argued by Barham since products result 'from long occupation of the same area' and they embody 'the interplay of human ingenuity and curiosity with the natural givens of place. ${ }^{115}$ This is not far from the truth since in the case

\footnotetext{
101 Barham (2003), pp. 127-138.

102 Barham (2003), pp. 127-138.

103 Barham (2003), pp. 127-138.

104 This goes in line with GI for services in which the terroir factor is not easily established.

105 Council Regulation (EC) No 509/2006 of 20 March 2006 on agricultural products and foodstuffs as traditional specialities guaranteed.

${ }^{106}$ Barham (2003), pp. 127-138.

${ }^{107}$ Gangjee (2017), pp. 129-130.

108 Gangjee (2017), pp. 129-130. He extends this as to establish that terroir is also crucial because it establishes the physical geography (literary) and thus draw the boundaries of the region of origin.

109 Barham (2003), p. 132.

${ }^{110}$ Food and Agriculture Organization of the United Nations (FAO) and SINER-GIFAO (2010).

111 Barham (2003), p. 130.

112 Barham (2003), p. 130.

113 Parasecoli (2017), p. 17.

114 Gangjee (2017), pp. 129-132.

115 Barham (2003), p. 131.
} 
of the production of baskets and pottery, the raw material used in these processes are what is 'available' to the community; at least this has been the case for the Wayuu and Zenú people. ${ }^{116}$ Similar to the case of the Chulucanas in Peru, looking at natural factors such as local clay and sand, the use of mango leaves, and the climate of the region. Using Chulucanas one can understand better the meaning of terroir. By observing at the manufacture process involved in the ceramics, one can notice how this goes in line with the explanation given by Wilson when he argues that the 'term' should not be taken lightly; there is a need to have 'reverence for the land which is a critical, invisible element of the term'. He continues by explaining that the 'true concept' is not simple, and that while it includes the 'physical elements' i.e. the habitat, beyond this 'there is an additional dimension - the spiritual aspect that recognizes the joys, the heartbreaks, the pride, the sweat, and the frustrations of its history. ${ }^{117}$ All this experience and the traditional techniques developed over a long period of time are accountable.

Certainly, such an essential link is still present between the product and place in cases of craft but to what degree can a regime, which was designed around the particularities of wines (which have a fundamental link and a crucial one with the region), be adapted to accommodate other GI products? ${ }^{118}$ This is a topic that needs further elaboration that escapes the scope of the present paper.

The fact is that when indigenous peoples are involved, there is a possible risk of losing the localized region of origin. Therefore, if DOs are only attached or deserve merit because of a physical 'region' of origin, the indigenous peoples will lose the right to use the DO. However, putting forward the example that the DO does not refer to the geographic name but actually to the name of the community, such as Wayuu and Zenú, the reputation is with the community rather than the region. Moreover, there is no possibility that if other producers manufacture the textile or pottery in the region where the DO is claimed to be from, they will be called Wayuu or Zenú because the DO name refers to the people's community rather than the region. Returning to the first point made regarding indigenous peoples losing their the right to use the DO because they were displaced, they may still be able to use a most flexible approach/system/regime if adopted by their national legislation e.g. GI or IS. In these systems, it is possible that no reference to the source of the raw materials is needed but specifies that all production steps be performed within a designated region. ${ }^{119}$ Finally noting the movement of the Geneva Act that introduced some flexibilities to the Lisbon Agreement by allowing the recognition for a reputation-based link, we can conclude that other types of regional specialities such as historical depth and human skills are considered. ${ }^{120}$ The EU regime has already recognised that reputation can be seen as an independent ground for justifying GI protection. ${ }^{121}$

\section{4. - Improving the livelihood of a community}

GIs support the setting-up of mechanisms that encourage manufacturing and thus, keeping alive a tradition; it helps to coordinate the establishment of regional centres for craftsmanship or creation of civic association of artisans; it benefits cultural mapping; encourage the government to award funding; ${ }^{122}$ assist to mobilize potential international

\footnotetext{
${ }^{116}$ A different debate is when practitioners migrate.

117 Wilson (1998), p. 55.

118 Gangjee (2017), pp. 129-133.

${ }^{119}$ See the example of Cantucci Toscani in Official Journal, L17, 26 January 2016.

${ }^{120}$ Gangjee (2017), pp. 129, 132.

${ }^{121}$ Exportur SA and LOR SA v Confiserie du Tech (C-3/91) (Turron case) [1992] ECR I-5529.

122 In France for example as other European countries the GI regime cost is heavily subsidized by the government, reflecting the importance they place on this type of production Barham (2003), p. 133.
} 
cooperation and interested parties; strength the mechanisms through which the element is passed on (educational environments) involving young generations ${ }^{123}$ (preserving their culture); promotes the organisation of exhibits; and incentive inventories ${ }^{124}$ which is a crucial practice when safeguarding TCEs, among other things. ${ }^{125}$ In general, it stresses the significance of the product in question by gaining recognition and driving national pride and cultural identity.

Some Latin American countries are encouraging the public to recognise the value of cultural heritage for the society itself, and to protect, safeguard and reward it. Indigenous peoples and rural communities are commonly affected by outside factors such as living in areas which are rich in natural resources (of interest to oil corporations and pharmaceutical companies) or areas that are affected by armed conflict and therefore bound to be displaced (voluntarily or not). ${ }^{126}$ In the case of Indigenous peoples they are commonly subjected to discrimination and ethnic stereotyping, leading to a denial of their cultural values; there is also the case of new generations becoming indifferent to their heritage. GIs ought then to be used to constructing policies that protect (preventing misappropriation) safeguard, preserve and promote culture. ${ }^{127}$

Producers may be already using a geographical name on their label, and others may be already engaging in collective promotional activities using a common logo. ${ }^{128}$ In the case of products coming from local communities be it rural areas and/or indigenous communities more engagement with such population is needed. They need a better understanding of the tools that exist due to the fact that products face competition from other goods, and even from counterfeit products which are produced in their national market and/or abroad. ${ }^{129}$ For example, as a personal anecdote, while on holiday in Turin, Italy last year, a Montecristi hat made in Panama (rather than Ecuador) was offered for sale (at a price over $€ 100$ ); on the same lines, in June 2017 in Cardiff, UK there was a stall in the street selling Wayuu bags (from £45) -- while made in Colombia they did not correspond to the analogous DO granted by the state.

Many studies look at how GIs have an economic impact on the region and how they are becoming a useful IPR for developing countries due to their potential to add value and promote rural socio-economic development. Adding to this, other factors are also included in the examinations such as: labour relations, social equalities and environmental issues. ${ }^{130}$ Calboli has persistently highlighted the unique benefits of GI protection, especially emphasizing how this can be used to stimulate the development of nichemarkets by creating a mechanism of rewards and accountability for producers; ${ }^{131}$ they may enable the prevention of depopulation and the creation of sustainable production that usually suffer from unemployment and thus, limiting migration to urban places. ${ }^{132}$ Usually

\footnotetext{
${ }^{123}$ According to Claude Vermont-Desroches, dedicated to the production of cheese Comté and chairman of the interprofessional committee of this milk in France asserts that young people prefer to stay in Comté since they "believe there is a future and they invest in improving this appellation of origin". See Indecopi (2011).

$124 \mathrm{Gl}$ does not mummified a product.

125 Covarrubia (2015).

${ }^{126}$ Covarrubia (2016), pp. 55-87.

${ }^{127}$ Covarrubia (2016), pp. 55-87.

128 Only recently Latin American producers are investing in the protection of their collective rights; however, it remains to be seen if they have the means to enforce them.

${ }^{129}$ See OriGin and Agridea (2009).

130 Parasecoli (2017), p. 20.

131 Irene Calboli (2015a), p. 760; Calboli (2015c), p. 373; Calboli (2015b), pp. 156-180.

132 Parasecoli (2017), p. 20.
} 
the art and craft sector shows levels of marginality and institutional weakness in relation to the management of its products. ${ }^{133}$

\subsection{Promoting rural entrepreneurship}

GI may help to alleviate poverty. ${ }^{134}$ The registration of a GI (which maximizes consumer certainty as to authenticity) when combined with an appropriate marketing strategy, can increase consumer recognition and help increase commercial benefits for communities. They are a valuable tool to help improve the economic position of such communities ensuring fair and equitable returns.

The 'Potato Park' in the region of Cuzco, Peru is noted for using the trade mark system to stimulate entrepreneurship through the use of the local knowledge and knowhow of farmers. ${ }^{135}$ Moreover, the Indecopi and the Food and Agricultural Organization (FAO) have launched a pilot project; these two institutions are working together supporting producers directing them on how to use in the most profitable way a DO they have obtained for Pallar de Ica (for beans). ${ }^{136}$ Indecopi has also carried out the task of disseminating and promoting the use of GIs and as a result more applications have been received in the last couple of years - bear in mind that from 1991 until 2005 Pisco was the only national DO. As part of this promotion was the launch of the book "Denomination of origin. Wonders of the Peruvian Spirit " which was made possible through the cooperation of the USAID Project, Trade Facilitation of the United States Agency for International Development. ${ }^{137}$

Collateral activities brought by the IP legal system have been observed such as ecotourism and sustainable tourism. See as an example Ecuador's project called 'Proyecto de Propiedad Intelectual, Turismo y Cultura'; the project was launched by WIPO using 4 countries, Ecuador being one of them. ${ }^{138}$

NGOs such as Ethik BGC which is a Canadian organization of artisans, makers, and eco-designers are working directly with Wayuu women artisans preserving their cultural heritage and increasing their quality of life. They have also partnered with FEM International, a Canada-based organization that connects with buyers. This has broadened market access and offer training for artisans. ${ }^{139}$

In Ecuador, there is 'Camari' an $\mathrm{NGO}^{140}$ comprising some 6,500 families aiming to promote fair trade and improve the living conditions of small agricultural and artisanal producers by assisting with production and selling methods. ${ }^{141}$ The Ecuadorian government put forward Resolution No. 004-2015 CD-IEPI which provided a $100 \%$ exemption for the recognition, inspections and authorizations of use of DOs until 31 December 2017.

There is also technical and financial support of the Spanish Agency of International Cooperation (AECI) which focuses on improving the competitiveness of the best Honduran coffees. The Inter-American Development Bank (IDB) and the Multilateral Investment Fund (MIF) have also play a crucial role in Central America by funding; in the

\footnotetext{
${ }^{133}$ See for example the request made by Colombia for international assistance from the Intangible Heritage Fund in 2017 - case File no. 01211.

134 Deepak (2008), p. 206.

${ }^{135}$ Argumedo and Pimbert (2018), pp. 1-16.

136 Indecopi (2011a).

137 Indecopi (2011b).

138 IEPI (2016).

${ }^{139}$ Waterman (2016).

${ }^{140}$ Camari has been registered as a collective trade mark in Ecuador.

141 International Living, Import-Export Opportunities in Ecuador (International Living Publishing Ltd., Ireland 2012).
} 
same vein, the Inter-American Institute for Cooperation on Agriculture (IICA) has given support to the coffee sector. ${ }^{142}$ All of these projects aim to promote rural entrepreneurship.

\subsection{Promoting handicraft}

By promoting handicraft as a GI product, it brings to it a premium, which will make the GI handicraft to be in a better position when competing with others products. A GI works as a marketing tool and as the 'production, distribution and consumption' are tangled in global flows, a GI may carry 'ideas and cultural trends' ${ }^{143}$ According to Parasecoli, by consumers knowing the meaning of the GI, they will connect with the origin, history and artisans behind the products and this will satisfy their emotional and aesthetic needs, which are not fulfilled by mass-produced items. ${ }^{144}$

Data confirms that GI is an economic tool but more debate about the role of GI (as well as other IP forms such as collective marks) in intangible cultural heritage preservation and safeguarding is needed. For instance, within the framework of the UNESCO 2003 Convention there has been an increase in number of registrations in the intangible list ${ }^{145}$ drawing attention to safeguarding and promoting dance and music as well as food and oral expression, but also some traditional art and handicraft have been inscribed as elements. From Latin America, in Ecuador there is the traditional weaving of the Ecuadorian toquilla straw hat ${ }^{146}$ - the Montecristi hat which refers to the Ecuadorian technique and toquilla straw used in the process (a registered DO in Ecuador). Peru has also inscribed, as element, the Taquile and its textile art, ${ }^{147}$ which is a weaving tradition from the people of Taquile that goes back to the ancient Inca, Pukara and Colla civilizations. Panama has inscribed the artisanal processes and plant fibers techniques for talcos, crinejas and pintas weaving of the pinta'o hat. ${ }^{148}$ GI application for these products is desirable, at least an intention to see its feasibility and benefits to its people is worth a try. As a good example, it is noticeable the report given by the EPIP in regard to the Montecristi hat. Accordingly, it has incremented its sales; improved the finished product and packaging; raised the number of people training in school workshops; improved basic services within the region like potable water and sewerage; and imparting training in export issues. ${ }^{149}$ Benefits are not only to the products and or producers alone, but also similarly to the surrounding environment, thus contributing to the entire production chain.

To end then, we need to examine the other side of the coin, since it is understood that GIs are not for everyone.

\section{3. - Great tool but not for me, thanks}

While all communities may see GI's potential, GI practicability and success is not always feasible. There are some weakness which are identifiable such as: socio-economic impacts, environmental consequences, complicated requirements for the artisanal sector, to name a few. Arzuza and Giuliani did a study in the framework of Colombia and Swiss Intellectual Property Project and they identified constraints for producing handicraft with natural raw materials. For instance, a negative impact on ecosystem degradation due to

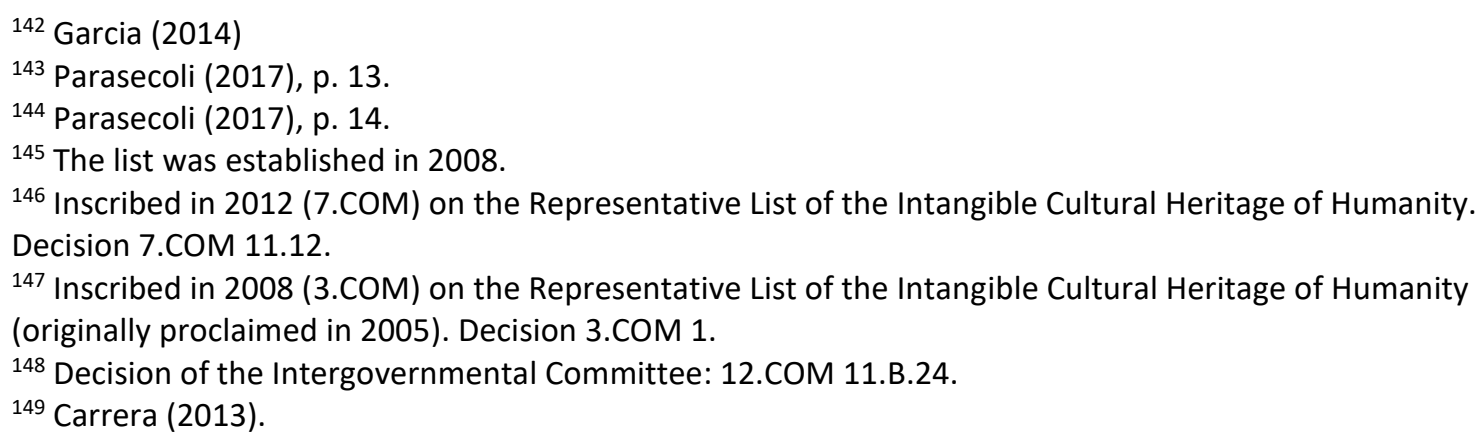


inadequate harvesting practices; increasing demand of handicraft affecting the scarcity of natural resources; and natural resources remaining undervalued in the production system due to lack of knowledge about the wild crops. ${ }^{150}$ They extended the study as to look at the aftermath and indicating that as the GI process finishes with the certification of the product as a GI, there were few points of contact from the governments to the artisans and also noting the lack of implementation of codes of practices. ${ }^{151}$ Moreover, the GI regime might prove burdensome for stakeholders and, for others, it may be expensive to register. Indecopi for example ruled out that the process to obtain a DO is cumbersome by stating that what one needs to be clear of is the procedure to obtain a DO. Yet, it noted that just by a DO being granted, it 'is not the end of the road, but an intermediate stage, because then comes the regulation of use and the regulatory council'. Other considerations that need to be noted are monetary constrains, which should not be limited to registration. There is the need to add appropriate marketing strategy to increase consumer recognition of the products and a budget to enforce the DO if needed.

To protect, preserve and safeguard traditional handicraft, a GI needs to be accompanied by other measures. Informing and promoting communities as well as consumers must be on the agenda; promoting networks of cooperation among producers, public bodies and tourist organizations and overall, the need of supporting rural production by eliminating overproduction so that the 'traditional' production can be sustainable. ${ }^{152}$

Other general constraints on benefiting producers are due to the lack of information because even if government officials are aware of the role of IPRs in economic development, the same awareness of GI has not yet reached out to producers, rural communities, business, and civil society; ${ }^{153}$ weak market power; lack of government's support to the stakeholders, ${ }^{154}$ lack of sensitization in GI; lack of collective organization and the lack of experience in the creation and management of such organizations (including financial and legal aspects). ${ }^{155}$ Insufficient communication between producers, traders and other actors, is also observed. Le Thi Thu Ha notes that there is a need to promote a healthy relationship between producers and inter-professional organizations that may guarantee the sustainability of GIs. ${ }^{156}$

Therefore, economic gain from GI cannot be only attributed to their registration. Proper management and the existence of a system like production monitoring, standard operating procedures and compliance is of crucial importance. ${ }^{157}$

\section{Conclusion and suggestions}

GIs have always had an economic rationale similar to the trade marks system. They make it easy for consumers to recognize origin and quality. While right holders build goodwill around their products (acquiring a premium price), on the other side of the coin, we see that the use of distinctive signs encourage 'cultural growth' of the market. ${ }^{158}$ That said a product will not only signify business but will also help stimulating tourism and raise the profile of an entire region while promoting cultural heritage. Moreover, aside

\footnotetext{
150 Melgarejo and Giuliani (2014).

151 Melgarejo and Giuliani (2014).

152 European Commission (2014).

153 Thi Thu Ha (2017), p. 44.

154 Melgarejo and Giuliani (2014).

155 Thi Thu Ha (2017), p. 45.

156 Thi Thu Ha (2017), p. 45.

157 Thi Thu Ha (2017), p. 47.

158 European Commission (2014).
} 
from the economic aim, many recognize that another objective of GI is to preserve 'traditions and skills passed down through generations'. ${ }^{159}$ Therefore, the concerns that the IP regime does not correspond to a positive duty to preserve TK and specifically TCEs, which has been used for commercial benefits, appear to no longer be a key problem. There are no grounds to limit the term 'protection' when covering GIs since preservation and safeguarding are too appropriate terms.

To conclude, GIs can be examined as a tool to $i$ ) improve the economy of a community; ii) preserve TCEs and iii) protect biodiversity (through the sustainable use of natural raw materials reducing genetic erosion). ${ }^{160}$ Nonetheless, there is a lack of awareness on the local innovation capabilities that these communities have and of the potential economic and cultural development and attention that they could obtain. It is suggested then that when referring to GIs for handicraft it should not be considered only as IPRs and thus, limiting the product to an economic tool. As a result, and seen that artisanal practice is currently undervalued, it will limit it as a 'product'. A traditional handicraft is more than a product, it is a local patrimony of the region.

What needs to be re-emphasized is the need to provide such protection in the national state before protecting in the international arena. Equal treatment to handicraft which can contribute to foreign exchange as well as to protect the heritage and traditional skills of making such products is vital. ${ }^{161}$ Indeed there is a need to bring EU legislation more into line with the international legal framework. ${ }^{162}$

The debate over GI protection should finally recognize the cultural interests that can be promoted as part of a comprehensive policy on GIs, and how this culture-related component should become a fundamental pillar of the ongoing discussions on GIs as traderelated instruments to promote local products in the international market.

\section{References}

Argumedo A and Pimbert M (2008) Protecting indigenous knowledge against biopiracy in the Andes. IIED, London, pp. 1-16

Ariza L and Parra A (2010) Protegiendo nuestra identidad. Bogotá: Ministerio de Comercio, Industria y Turismo y Artesanías de Colombia S.A., p. 10

Barham E (2003) Translating terroir: the global challenge of French AOC labelling. Journal of Rural Studies 19: 127-138

Calboli I (2015a) Geographical indications of origin at the crossroads of local development, consumer protection, and marketing strategies. Int'1 Rev Intell Prop \& Competition L 46(7): 760

Calboli I (2015b) Intellectual property protection for fame, luxury, wines, and spirits: Lex Specialis for a corporate "Dolce Vita" or a "Good Quality Life"? In:

Dinwoodie G (eds) Intellectual property and general legal principles: is IP a Lex Specialis? Edward Elgar Publishing, pp. 156-180

Calboli I (2015c) Time to say local cheese and smile at geographical indications of origin? International trade and local development in the United States. HousLR 53: 373 Chan AS (2014) Networking peripheries: technological futures and the myth of digital universalism. MIT Press, Massachusetts

\footnotetext{
${ }^{159}$ European Commission (2014).

160 Melgarejo and Giuliani (2014). See also WIPO (2017).

161 The Times of India (2013).

162 European Commission (2014).
} 
Carrera G L (2013) Denominaciones de Origen en el Ecuador. Consorcios de Origen' (paper presented in Bogotá, Colombia,11 December 2013, sponsored by the Ecuadorian national Intellectual Property Office and Artesanías de Colombia).

Castonguay S (2006) Arts and crafts of Colombia. WIPO Magazine Issue 6, http://www.wipo.int/wipo_magazine/en/2006/06/article_0002.html. Accessed on 10 October 2018

Covarrubia P (2016) Colombia: intellectual property and aboriginal handicraft. In: Sargent $S$ and Samanta J (eds) Indigenous rights-changes and challenges for the $21^{\text {st }}$ century. The University of Buckingham Press

Covarrubia P (2011) The EU and Colombia/Peru free trade agreement on GIs: adjusting Colombian and Peruvian national laws? Journal of Intellectual Property Law and Practice 6(5):330-338

Covarrubia P (2017) France and Peru present cooperation action. IPtango, blog, http://iptango.blogspot.co.uk/2017/03/france-and-peru-present-cooperation.html. Accessed on 22 June 2018

Covarrubia P (2015) Geographical Indications: to be or not to be (some thoughts). IPtango, blog, http://iptango.blogspot.co.uk/search?q=geographical+indication. Accessed 06 June 2018

Covarrubia P (2016) Protection of non-agricultural GIs: a window on what is happening in Latin America. European Intellectual Property Review 38(3):129-131

De la Cruz R (2006) Conocimientos tradicionales y el derecho consuetudinario. Unión Mundial para la Naturaleza (UICN) Documento Revisado, Chile

Deepak J (2008) Protection of traditional handicraft under Indian intellectual property. Journal of Intellectual Property Rights 13: 197-207

European Commission (2014) Results of the public consultation and public conference on the Green Paper Making the most out of Europe's traditional know-how: a possible extension of geographical indication protection of the European Union to nonagricultural products (COM(2014) 469 final (15 July 2014)

European Commission, Results of the public consultation and public conference on the Green Paper Making the most out of Europe's traditional know-how: a possible extension of geographical indication protection of the European Union to non-agricultural products (COM(2014) 469 final (15 July 2014).Fernandez C (2017) Protecting collective intellectual property: the case of the Mayan women. IPtango, blog, http://iptango.blogspot.co.uk/2017/03/protecting-collective-intellectual.html. Accessed 28 June 2018

Food and Agriculture Organization of the United Nations (FAO) and SINERGIFAO (2010) Linking people, places and products: A guide for promoting quality linked to geographical origin and sustainable geographical indications. Second edition FAO, http://www.fao.org/docrep/013/i1760e/i1760e.pdf, p. 3. Accessed 07 June 2018

Gangjee D (2017) GIs beyond wine: time to rethink the link? Int'l Rev Intell Prop \& Competition L 48(2): 129-133

Garcia A (2014) Presentan nuevas denominaciones de origen e indicación geográfica del café centroamericano. IICA Noticias, http://www.iica.int/es/prensa/noticias/presentan-nuevas-denominaciones-de-origen-eindicaci\%C3\%B3n-geogr\%C3\%A1fica-del-caf\%C3\%A9. Accessed on 23 June 2018

Gervais DJ (2009) Traditional knowledge: are we closer to the answers? The potential role of geographical indications. ILSA Journal of International and Comparative Law 15(2):555, 560

Goss I (2017) Information note for IGC 33. Note from the WIPO Secretariat: The chair of the IGC. WIPO/GRTKF/IC/33 
IEPI (2016) Proyecto de propiedad intelectual, turismo y cultura. IEPI Boletín No. 071, https://www.propiedadintelectual.gob.ec/ecuador-forma-parte-del-proyecto-pilotopropiedad-intelectual-turismo-y-cultura/. Accessed on 08 June 2018

Indecopi (2011a), INDECOPI y la FAO capacitan a productores para vender con éxito productos con denominación de origen. Indecopi Noticias 08 November 2011, https://www.indecopi.gob.pe. Accessed 13 June 2018

Indecopi (2011b) Productores son esenciales para lograr el éxito de las denominaciones de origen. Indecopi Noticias, 23 June 2011, https://www.indecopi.gob.pe, accessed 09 June 2018

Lenzerine F (2011) Intangible cultural heritage: the living culture of peoples. European Journal of International Law 22(1): 108

Lucas C (2014) Indicaciones geográficas: competitividad y mercadeo. Estrategia y Negocios, newspaper, Honduras

Marie-Vivien D (2016) A comparative analysis of GIs for handicrafts: the link to origin in culture as well as nature? In: Gangjee D (eds) Research handbook on intellectual property and geographical indications. Edward Elgar Publishing pp. 292-326

Marie-Vivien D (2017) Do geographical indications for handicrafts deserve a special regime? Insights from worldwide law and practice. In: van Caenegem $\mathrm{W}$ and Cleary J (eds) The importance of place: geographical indications as a tool for local and regional development. Springer International Publishing pp 221-252

Melgarejo J and Giuliani A (2014) Geographical indications of handicraft: a tool to improve livelihood and protect biopiracy in remote communities? Conference on International Research on Food Security, Natural resource Management and Rural Development, Tropetag, https://www.bfh.ch/fileadmin/data/publikationen/2014/11_Giuliani_Geographical_Indicat ors.pdf. Accessed on 12 October 2018

OMPI (2012) Panamá: tres marcas para el desarrollo. Revista de la OMPI 2/2012, Geneva

OriGin and Agridea (2009) Study on the protection of geographical indications for products other than wines, spirits, agricultural products or foodstuffs. Study commissioned by the Directorate General for Trade of the European Commission, Geneva

Paz J and Pomareda C (2009) Indicaciones geográficas y denominaciones de origen en Centroamérica: situación y perspectivas. Policy discussion paper, Centro Internacional para el Comercio y el Desarrollo Sostenible - International Centre for Trade and Sustainable Development (ICTSD) pp. 1-23

Parasecoli F (2017) Geographical indication, intellectual property and the global market. In: May S, et al. (eds), Taste - Power-Tradition: Geographical indications as cultural property. Göttingen Studies in Cultural Property, Volume 10: 13-14, 17, 20

The Economist (2017) Building bridges -Latin America's new trade agenda: A report by The Economist Intelligence Unit. The Economist

The Times of India (2013) We must protect traditional Indian products in the international market to boost growth. The Times of India (New Deli, 21 January 2013).

Thi Thu Ha L (2017) Facilitating the protection of geographical indications in ASEAN. SECO/WTI Academic Cooperation Project Working Paper Series 2017/01. https://ssrn.com/abstract=2905623. Accessed 09 July 2018

UNESCO.ITC (1997) International symposium on craft and the international market: Trade \& Custom Codification FINAL REPORT. CLT/CONF/604/7

Waterman A (2016) Artisan Report: EXPOARTESANÍAS, Colombia. The Kindcraft, http://thekindcraft.com/artisan-report-expoartesanias-colombia/. Accessed on 22 June 2018 
Wilson J (1998) Terroir: The role of geology, climate and culture in the making of French wines. Mitchell Beazley, London p. 55

WIPO (2015) Panama: Empowering indigenous women through a better protection and marketing of handicrafts,

http://www.wipo.int/wipo_magazine/en/2005/06/article_0005.html. Accessed on 10 October 2018

WIPO (2017) Protect and promote your culture: A practical guide to intellectual property for indigenous peoples and local communities,

http://www.wipo.int/edocs/pubdocs/en/wipo_pub_1048.pdf. Accessed on 12 October 2018 